\title{
PROPAGANDA FIREHOSE OF FALSEHOOD PADA PEMILU 2019 DI INDONESIA
}

\author{
Achmad Haqqi \\ Universitas Paramadina, Jakarta \\ achhaqqi75@gmail.com
}

\begin{abstract}
This article discusses the firehose of falsehood propaganda that occurred in Indonesia, in the presidential and vice presidential elections in 2019, was a political campaign strategy that was know effective sufficient to achieve one goal such as what Donald Trump did in elections in the United States of America. The social media burgeoned was so enable for every candidate to use the firehose of falsehood propaganda technique without exception in Indonesia. In the case of the 2019 presidential and vice presidential elections, we can see how campaigns are used on social media such as the spread of hate speech, the emergence of the term kampret, cebong, anti-islam, boyolali,PKI, to hoaxs issues, and so on. What is conveyed contains a minimum of a work program to be achieved, this shows that the two pairs of candidates each use the firehose of falsehood propaganda technique to achieve their goals. The method used in this research is descriptive qualitative which constructivism paradigm which aims to describe a social phenomenon under study. The date collection method by interviewing, analyzing documentsand using the case study method in the 2019 presidential and vice presidential elections in Indonesia.
\end{abstract}

Keywords : propaganda, firehose of falsehood,2019 election

Artikel ini membahas tentang Propaganda firehose of falsehood yang terjadi di Indonesia, pada pemilihan Presiden dan Wakil Presiden di tahun 2019 kemarin, teknik ini merupakan sebuah strategi kampanye politik yang diketahui cukup efektif untuk mencapai satu tujuan sebagaimana yang dilakukan oleh Donald Trump dalam pemilu di Amerika Serikat pada tahun 2016. Berkembangnya media social sangat memungkin bagi setiap calon untuk menggunakan teknik propaganda firehose of falsehood tidak terkecuali di Indonesia. Dalam kasus pemilihan Presiden dan Wakil Presiden tahun 2019 dapat kita lihat bagaimana cara kampanye yang dipakai di media sosial seperti merebaknya ujaran kebencian, munculnya istilah kampret, cebong, antiislam, boyolali, PKI, hingga isu hoax, dan sebagainya. Apa yang disampaikan minim berisi program kerja yang ingin dicapai. ini menunjukkan bahwa kedua pasangan calon masing-masing menggunakan teknik propaganda firehose of falsehood untuk mencapai tujuannya. Metode yang digunakan dalam penelitian ini, menggunakan metode kualitatif deskriptif dengan paradigma konstuktivisme yang bertujuan untuk mendeskripsikan suatu fenomena sosial yang diteliti. Adapun metode pengumpulan data yaitu dengan wawancara, analisis dokumen serta menggunakan metode studi kasus pada pemilihan Presiden dan wakil presiden tahun 2019 di Indonesia.

Kata Kunci : Propaganda, Firehose Of Falsehood, Pemilu 2019

\section{PENDAHULUAN}

Istilah firehose of falsehood, merupakan suatu teknik propaganda yang sudah dikenal sejak lama dalam dunia politik. Dimana seseorang menyampaikan pesan lewat media massa dengan berbagai macam cara untuk memperoleh simpati masyarakat umum, dan di Indonesia sendiri, model tersebut semakin terlihat dalam pemilihan presiden dan wakil presiden 2019-2024, antara pasangan calon nomor urut 01 yaitu Joko widodo dan Ma'ruf Amin, dengan kualisi partai pengusungnya antara lain; PDIP,Golkar, PPP, PKB,dan lainlainnya. Sementara dari pihak lawan yakni, pasangan calon nomor urut 02 Prabowo Subianto dan Sandiaga Salahuddin Uno,yang 
di usung oleh kualisi partai PKS, Gerindra, dan PAN.

Dalam kampanye seseorang melakukan berbagai cara untuk memperoleh kemenangan atas dirinya dan kelompoknya, sehingga ia melakukan propaganda yang dianggap akan mampu memberikan hasil signifikan. Namun semua itu tentu ada strategi pemasarannya. Bruce I Newman, mendefinisikan Marketing adalah proses memilih customer, kemudian menganalisa kebutuhannya, dan setelah itu mengembangkan inovasi produk, advertising, harga, dan strategi distribusi dalam basis informasi. Marketing bukanlah sesuatu yang biasa karena marketing merupakan sebuah produk politik yang berupa image politisi, platform, pesan politik, dan lain sebagainya yang dikirimkan ke audiens kemudian diharapkan menjadi konsumen yang tepat.

Newman menegaskan, bahwa dalam peta marketing kandidat (candidate marketing map), terdapat enam tahapan yang mesti diperhatikan yaitu; Riset lingkungan (environment research); yaitu setting dan konteks dimana seorang kandidat mengorganisasi sebuah kampanye. Misalnya, pada tahapan ini meriset situasi ekonomi, mood pemilih (voter satisfaction or dissatisfaction), isu dan konsen penting pemilih,peta demografi pemilih, riset partai dominan atau independen.; Analisis penilaian internal dan eksternal. Disini si kandidat mesti menilai kekuatan dan kelemahan dirinya, status kandidat sebagai incumbent atau penantang, peluang isu-isu kampanye, serta kekuatan dan kelemahan kompetitor.; Marketing strategis, misalnya terkait dengan segmentasi pemilih (usia, income, pendidikan, etnis, ideologi kelompok, dan sebagainya), target dan positioning (citra kandidat versus citra lawan).; Setting tujuan dan strategi kampanye (goal setting and campaign strategy), misalnya menyangkut positioning latar belakang dan kualifikasi, pesan utama kampanye, pemilihan isu dan solusi konsep pribadi kandidat, dan lain sebagainya.; Komunikasi, distribusi, dan perencanaan organisasi (communication, distribution, and orgazation plan). Dalam tahapan ini misalnya, lebih menekankan pada sosok penampilan, publisitas, iklan dan pemilihan pesan, format serta desain medianya.; Dan terakhir adalah pasar-pasar (massa) utama dan hasil (key markets and outcomes) yang berkaitan dengan segmen konstituen pemilih partai, segmen kontributor, segmen media, dan publisitas (Heryanto, 2018: 241-242)

Tidak bisa kita pungkiri bahwa semua itu, berkaitan dengan komunikasi politik sebagai suatu sistem politik. Gabriel Almond, berpendapat bahwa komunikasi adalah salah satu fungsi yang selalu ada dalam setiap sistem politik. "All of the functions performed in the political system, political socialization and recruitment, interest articulation, interest aggregation, rule making, rule application, and rule adjudication, are performed by means of communication."Artinya bahwa komunikasi politik merupakan proses penyampaian pesan yang terjadi pada saat keenam fungsi lainnya itu dijalankan. Hal ini berarti bahwa fungsi komunikasi politik terdapat secara inherent di dalam setiap fungsi sistem politik (Gabriel A. Almond dan James S. Coleman, 1960)

Sebagaimana yang disebut diatas bahwa marketing komunikasi politik oleh setiap kandidat itu sangat diperlukan maka munculah istilah propaganda. Propaganda itu sendiri dalam politik berfungsi untuk memainkan peran yang sangat penting karena merupakan satu di antara pendekatan persuasif politik selain periklanan dan retorika. Dalam praktiknya, propaganda mengelaborasi pesan politik guna mendapatkan pengaruh secara persuasif. Biasanya, propaganda digunakan oleh seseorang atau sekelompok orang terorganisasi yang ingin menciptakan partisipasi aktif atau pasif dalam tindakan individu-individu masyarakat yang dipersatukan melalui manipulasi psikologis lewat media massa.

Menurut jacques ellul, dalam Dan Nimmo (1993:48) propaganda sebagai komunikasi yang digunakan oleh suatu kelompok terorganisasi yang ingin menciptakan partisipasi aktif atau pasif dalam 
tindakan-tindakan suatu massa yang terdiri atas individu-individu, dipersatukan secara psikologis melalui manipulasi psikologis dan digabungkan di dalam suatu organisasi. Harold D. Haswell, menambahkan sebagaimana dikutip Arifin, (2010:230) mendefinisikan propaganda adalah teknik yang mempengaruhi tindakan manusia dengan memanipulasi presentasi (penyajian). Representasi bisa berbentuk lisan, tulisan, gambar, atau musik, sehingga periklanan dan publisitas ada didalam wilayah propaganda.

Sementara itu, propaganda menurut Gobbels membawa pengaruh negatif ketika hal itu dipraktikkan dalam perang Dunia II. Dimana pada waktu itu, menteri Propaganda Jerman Dr. Joseph Gobbels mengatakan bahwa "propaganda tidak tidak mengenal aturan dan etika. Tujuannya adalah membelenggu rakyat dengan segala cara untuk mencapai tujuan yang yang diinginkan." Doktrin politik Machiavelli yang mengabaikan relevansi moral, dimana ketidak jujuran dibenarkan dalam mencari dan mempertahankan kekuatan politik (Hafied Cangara, 2009:333)

Dan disaat kebanyakan orang mencela tindakan propaganda Gobbel karena dianggap mencederai moralitas dan kemanusiaan Edward Barnays justru melihat pada sisi lain bahwa propaganda bukanlah merupakan sebuah usaha yang patut dicela dalam meracuni pikiran seseorang dengan penuh kebohongan, melainkan lebih dari itu yakni suatu usaha yang terkelola untuk menyebarluaskan sesuatu untuk mendapatkan kepercayaan atau opini. Sehingga propaganda menurut Barnays sangat dibutuhkan bagi peradaban umat manusia (Hafied Cangara, 2009:334)

Sehingga bagaimana kemudian cara menjalankannya ? seringkali beroperasi melalui imbauan-imbauan yang itu biasanya berjangka pendek. dengan melibatkan usaha pemerintah, partai politik, atau golongan tertentu yang berpengaruh untuk mencapai tujuan strategis dan taktis.
Kampanye Hitam selalu menyerang pihak lain dengan gosip atau rumor yang tak bisa dipertanggungjawabkan. Sumber penyebar pesan kampanye tidak jelas, samar, bahkan seringkali secara sengaja bergerak dalam operasi gelap dan tak tersentuh proses dialektika. Beberapa teknik kampanye hitam disini seringkali dipakai dalam perang opini dimasyarakat dengan menggunakan teknik propaganda. Pertama, teknik name calling, yang artinya pemberian lebel buruk pada lawan seperti melabeli kandidat dengan sebutan dan stigmayang sangat buruk sebagaimana yang terjadi pada pemilihan presiden kemarin yang saling memberi label satu sama lain (Heryanto, 2018:225).

Propaganda sendiri berasal dari kata propagare, artinya menyemaikan tunas suatu tanaman, yang pada awalnya digunakan dalam bidang keagamaan oleh penganut agama katolik. Pada tahun 1622, paus gregorius XV membentuk suatu komisi kardinal, yang bernama congregatio de propaganda fide atau congregation for the propagation of faith untuk menumbuhkan keimanan kristiani diantara bangsa-bangsa. secara khas, para misionaris ditugaskan untuk menyebarkan doktrin kristiani tersebut, yaitu seorang misionaris harus mampu menggalang beberapa ribu pemeluk baru yang diharapkan (Arifin, 2010:229)

Adapun propaganda dalam sejarah pemikiran politik adalah adanya argumen utama yang cukup meyakinkan dan sudah dikenal sejak zaman Plato, yang akan menuntun kita untuk berfikir panjang bahwa berharap pada demokrasi liberal yang kuat sekalipun hanyalah sebuah nama saja, akan tetapi pada realitasnya jauh dari harapan kita. Argumen seperti ini merupakan suatu bentuk propaganda tertentu yang berkaitan dengan demagog, yang bisa menjadi ancaman eksistensial terhadap keberadaan demokrasi liberal. Sifat demokrasi liberal mencegah pernyataan propaganda dilarang, karena di antara kebebasan yang diizinkannya adalah kebebasan berbicara. Tetapi karena manusia memiliki karakteristik kelemahan rasional dan 
rentan terhadap sanjungan dan manipulasi, memungkinkan propaganda memiliki kemungkinan besar untuk memimpin tirani, ke akhir demokrasi liberal (Stanley, 2015:27)

Dalam bahasa Inggris, kata "propaganda" telah memperoleh koneksi penghinaan. Dan tidak memiliki konotasi yang merendahkan seperti dalam tulisan penulis Amerika pada awal abad kedua puluh, alasan historis ini tidak diragukan lagi. Orang bisa membayangkan kata "propaganda" memungkin ada sesuatu yang salah utamanya tentang penggunaan propaganda dalam demokrasi liberal, apa pun tujuannya. Tapi jenis tertentu propaganda sangat bermasalah secara moral dan politik. Saya akan menggunakan kata "penghasutan" sebagai label untuk propaganda dalam segala hal yang dianggap tidak masuk akal ini (Stanley, 2015:37).

Sementara itu, kalau kita merujuk pada konsep politik dari sejak awal hingga perkembangannya terdapat beberapa pandangan mengenai politik yaitu; pertama, politik adalah suatu usaha yang ditempuh warga negara untuk membicarakan dan mewujudkan kebaikan bersama. Kedua, politik dikenal sebagai segala hal yang berkaitan dengan penyelenggaraan negara dan pemerintahan. Ketiga, politik sebagai segala keegiatan yang diarahkan untuk mencari dan mempertahankan kekuasaan dalam masyarakat. Keempat, politik sebagai kegiatan yang berkaitan dengan perumusan dan pelaksanaan kebijakan umum. Kelima, politik diartikan sebagai konflik dalam rangka mencari dan/atau mempertahankan sumbersumber yang dianggap penting. Dalam pandangan klasik Aristoteles, mengungkapkan bahwa manusia merupakan mahluk politik sehingga hakikat manusia memang untuk hidup dalam polis. Karena hanya dalam polis manusia bisa memperoleh sifat moral paling tinggi (Ramlan Surbakti, 2007:1-2)

Politik merupakan sebuah laga para aktor politik dalam mengartikulasikan, memformulasika, dan mewujudkan cita-cita sosialnya dalam kehidupan di masyarakat yang lebih komplek. Karena itu, pada kontestasi politik setiap individu memiliki kesempatan dan peluang yang sama dalam mendiskusikan, merumuskan, dan memutuskan aspek penting dalam kehidupan publik. namun, adanya kecenderungan yang kuat mendorong terjadinya peluang hanya pada beberapa orang yang dikehendaki untuk kemudian di branding dan dimenangkan bersama.

Kalau kita lihat di Indonesia sendiri misalnya, terdapat beberapa aktor-aktor politik antara lain; seperti Megawati, yang tidak lain adalah anak mantan dari sang proklamator sekaligus presiden pertama, atau Abdurrahman Wahid yang biasa dikenal dengan sebutan Gus Dur, dan lain-lainnya (Nyarwi,2012: 46). Para aktor-aktor ini, yang kemudian selalu berusaha untuk mempertahankan apa yang dia kuasai sejauh ini. Sehingga dengan berkembangnya media massa, para aktor semakin memiliki banyak kesempatan untuk membranding dirinya lewat media massa dengan berbagai macam cara (mempropaganda) masyarakat agar simpati padanya.

Di era media cetak, juga media penyiaran radio, proses komunikasi politik masih di dominasi oleh adanya pertarungan ideologi dan pemikiran politik. Karakter media cetak terutama koran dan majalah mampu menghadirkan ragam ideologi dan pemikiran politik dari para aktor politik dan institusi politik. Di berbagai belahan negara, proses komunikasi politik yang berlangsung di era dominasi peran media cetak ini, dibarengi dengan munculnya intelektualitas dan literasi komunikasi dari para pemilihnya. Pemikiran politik dan ideologi politik yang berbasis kebajikan publik (public wisdom), terus diperdebatkan dan didiskusikan dalam arena ruang publik (Nyarwi, 2012:67)

Dalam kehidupan hari ini, propaganda menjadi suatu keharusan bagi para politisi untuk menampuh atau menggunakan cara-cara tersebut, sebagai upaya mencapai satu tujuan yang diinginkan. Karena jika para aktor politik apatis dan cenderung kurang mampu membaca peluang dimasyarakat maka secara otomatis dia akan kalah sebelum waktunya. 
Perebutan kekuatan oleh Bolsheviki pada tahun 1917 sudah meningkatkan prestise propaganda yang populer. Sudah dipuji sebagai kemenangan hasutan massal. Dari waktu itu awal di Moskow pada tahun 1919, Internasional Ketiga adalah disebut dunia konspirasi melawan patriotisme, sebuah propaganda dunia melawan nasionalisme. Prestise propaganda semakin maju dalam kebangkitan fasisme pasca-perang di Italia, yang sering dikaitkan dengan sebagian besar untuk kekuatan agitasi dan keterampilan Mussolini.

Kesadaran propaganda tumbuh di antara orang Amerika sebagai akibat dari internal maupun eksternal propaganda. Setelah akhir Perang Dunia, banyak kelompok bisnis Amerika berusaha untuk melepaskan kendali atas bisnis yang telah mapan selama perang, dan untuk menarik konsesi diberikan untuk tenaga kerja terorganisir. Kampanye propaganda diluncurkan melawan pemerintah dan buruh, tema utama menjadi ancaman Bolshevisme ke Amerika (Laswell dan Blumenstock,2006: 3). Dan Ketika pemberitahuan publik secara dramatis tertarik pada propaganda oleh kelompok bisnis, kesadaran propaganda sebagai instrumen politik dibuat semua lebih tajam. Publik investigasi dilakukan terhadap propaganda yang luas kampanye dari banyak perusahaan utilitas publik yang bertindak melalui Asosiasi Cahaya Listrik Nasional. Ketakutan baru terhadap Komunis propaganda terstimulasi ketika besar Depresi semakin dalam setelah 1929. Di tingkat nasional darurat kekuasaan pemerintah federal sangat besar diperpanjang, terutama setelah pemilihan Presiden Roosevelt di 1932 (Harold D Laswell, 2006:4).

Sehingga dari sanalah kemudian propaganda mulai menjadi sebuah agenda setting yang utama dalam sebuah politik oleh karena itu, seorang propagandis profesional didefinisikan sebagai orang yang mempraktikkan profesi dari publisitas atau pakar propaganda selalu menjadi konsultan untuk memberikan saran atau masukan kepada seorang politisi (Harold D Laswell, 2006:5)
Berdasarkan uraian latar belakang masalah diatas, maka fokus dalam penelitian ini adalah: Apakah kedua pasangan calon Presiden dan Wakil Presiden, menggunakan tekni Propaganda firehose of falsehood pada pemilihan Presiden yang terjadi di tahun 2019 kamarin. Tujuan penelitian ini adalah sebagai upaya untuk menggambarkan perjalanan pemilihan presiden dan wakil presiden yang terjadi di tahun 2019 kemarin.

\section{METODOLOGI}

Dalam penelitian ini, peneliti menggunakan metode kualitatif dengan pendekatan paradigma konstruktivisme yang bertujuan untuk mendeskripsikan suatu fenomena sosial yang diteliti. Metode penelitian kualitatif adalah metode penelitian yang berlandaskan pada filsafat postpositivisme, digunakan untuk meneliti pada kondisi obyek yang alamiah, (sebagai lawannya adalah eksperimen) dimana peneliti adalah sebagai instrumen kunci, pengambilan sampel sumber data dilakukan secara purposive dan snowbaal, teknik pengumpulan dengan trianggulasi (gabungan), analisis data bersifat Induktif/kualitatif, dan hasil penelitian kualitatif lebih menekankan makna pada generalisasi (Sugiono, 2011:15)

Adapun yang dimaksud dengan pendekatan paradigma konstruktivisme menurut (Salim, 2006:51), yaitu sebuah paradigma yang hampir merupakan antithesis terhadap paham yang menempatkan pentingnya suatu pengamatan dan objektivitas dalam menemukan suatu realitas atas ilmu pengetahuan. Dimana secara ontologis pendekatan ini menyebutkan bahwa suatu realitas ada dalam beragam bentuk konstruk mental yang didasarkan pada pengalaman sosial, dan spesifik, serta tergantung pada pihak yang melakukannya.

Penelitian kualititaf diharapkan mampu menghasilkan uraian yang mendalam tentang suatu keadaan baik berupa tulisan, ucapan langsung, atau perilaku seseorang baik individu, maupun kelompok yang bisa diamati, 
dalam sudut pandang tertentu, secara komprehensif (Sujarwandi, 2014:6)

Berdasarkan pengertian diatas peneliti memberi kesimpulan bahwa metode kualitatif merupakan suatu metode yang obyektif artinya metode yang selalu memiliki obyek alamiah yang dapat dideskripsikan bukan yang berbentuk eksperimen. Dalam penelitian ini, peneliti menggunakan pendekatan kualitatif sebab peneliti ingin mendapatkan hasil yang deskripstif dari obyek yang diteliti berupa ucapan atau tulisan.

Adapun teknik pengumpulan data dalam penelitian ini, yaitu Teknik wawancara dimana penulis langsung mewawancarai sumber terkait yang terlibat secara langsung dalam suatu peristiwa dan kedua adalah studi pustaka dimana setelah peneliti menetapkan topik penelitiannya, kemudian melakukan kajian yang ada kaitannya dengan teori, serta mengumpulkan informasi sebanyak mungkin dari pustaka yang masih ada kaitannya dengan tema. sumber-sumber tersebut dapat diperoleh darimana saja seperti dari jurnal, majalah, buku, berita, atau sumber-sumber lain yang masih relevan.

\section{HASIL DAN PEMBAHASAN}

Dalam hal penelitian terkait Propaganda firehose of falsehood dalam pemilu tahun 2019 di Indonesia, terdapat penelitian serupa yang dilakukan oleh beberapa pihak. Diantaranya penulis menemukan ada kemiripan judul namun berbeda objek dan subtansi kajiannya. Terdapat Analisis Wacana yang bertemakan politik, yaitu pertama Jurnal Golose, (2019) dengan judul "Strategi penanganan firehose of falsehood pada Era post-truth" sebuah kajian dalam rangka menyukseskan pemilu 2019.

Jenis penelitian ini bersifat deskriptif kualitatif, dimana data yang dihasilkan berupa data deskriptif tertulis atau lisan. Jurnal ini membahas mengenai propaganda firehose of falsehood dalam rangka meningkatkan tingkat kepercayaan dari masyarakat pada pemilu 2019. Adapun yang menjadi objek dalam penelitian ini adalah konten pemberitaan hoax dan citra institusi Kepolisian Republik
Indonesia. dengan menggunakan metode analisis deskriptif dengan menonjolkan aspek tertentu atau realita berita dari suatu media.

Perbedaan dengan artikel penulis ialah terletak pada pokok permasalahannya, penggunaan media dan paradigma yang dipakai. Jika artikel diata meneliti tentang Strategi penanganan firehose of falsehood pada era post-truth. Sedangkan penulis meneliti tentang Propaganda Firehose of Falsehood pada pemilihan presiden dan wakil presiden 2019 dengan menggunakan pendekatan deskriptif kualitatif dan menggunakan paradigma konstruktivisme.

Penulis kedua yaitu (Damayanti \& Hamzah, 2017) dengan judul "Strategi Kampanye Politik pasangan Jokowi-JK pada pemilihan Presiden 2014". Dan jenis penelitian yang digunakan adalah deskriptif kualitatif dengan paradigma konstruktivisme. Jurnal ini membahas mengenai gaya atau pola yang digunakan kedua pasangan calon untuk memperoleh simpati masyarakat.

Perbedaan artikel penulis dengan artikel kedua ini terletak pada pokok permasalahan yang dikaji, dalam artikel ini membahas soal strategi kampanye pasangan calon presiden Jokowi-JK pada pemilu 2014. Sementara penulis meneliti tentang Propaganda Firehose of Falsehood pada pemilihan presiden dan wakil presiden 2019 dengan menggunakan pendekatan deskriptif kualitatif dan menggunakan paradigma konstruktivisme.

Teori media masyarakat massa adalah sesuatu yang dapat dianggap sebagai kumpulan gagasan yang saling bertentangan dikembangkan untuk memahami apa yang terjadi setiap kali ada skala besar dan/atau perubahan sosial yang mengganggu. Gagasan masyarakat massa dapat berasal dari kedua ujung spektrum politik. Beberapa dikembangkan oleh orang-orang yang ingin mempertahankan tatanan politik yang ada, dan yang lain diciptakan oleh kaum revolusioner yang ingin memaksakan perubahan radikal. Tapi musuh ideologis ini sering berbagi setidaknya satu asumsi media massa menyusahkan jika tidak benar-benar 
berbahaya. Secara umum, masyarakat massa ide-ide memiliki daya tarik yang kuat untuk setiap elit sosial yang kekuatannya terancam oleh perubahan. Industri media, seperti pers sen di tahun 1830-an, jurnalisme kuning di Jakarta, 1890-an, film pada 1920-an, radio pada 1930-an, dan TV pada 1950-an adalah sasaran empuk kritik para elit (Stanley \& Davis, 2013:20).

Dalam konteks media sosial Lattimore (2010), mengungkapkan bahwa media sosial merupakan salah satu produk dari kemunculan new media. Didalam media sosial individu maupun kelompok saling berinteraksi secara online melalui jejaring internet dan semenjak kemunculannya media sosial tidak hanya dipergunakan oleh individu saja melainkan juga oleh kelompok atau golongan sebagai alat komunikasi yang dianggap cukup membantu bahkan juga dipergunakan sebagai alat komunikasi yang efektif untuk tegur sapa kepada public. Media sosial yang terkadang diidentifikasi dengan web 2.0 merupakan istilah yang seringkali mengacu pada media baru yang menggunakan teknologi dalam menciptakan interaksi, partisipasi, dan kolaborasi terbuka dimana setiap orang mempunyai kesempatan untuk menyuarakan ide, atau gagasan, serta pengalaman mereka melalui media sosial baik dalam bentuk katakata atau dalam bentuk verbal. (Srisadono, 2018:4)

Sedangkan komunikasi massa adalah suatu pesan yang dikomunikasikan melalui media massa pada sejumlah besar orang. komunikasi massa diadopsi dari bahasa inggris yaitu mass communication yang bermakna komunikasi menggunakan media massa. Kata massa disini bukan hanya meliputi orang banyak, tetapi semua orang yang menjadi sasaran antara atau sebagai alat komunikasi. Jadi kesimpulannya adalah setiap pesan yang disampaikan melalui media massa baik cetak, siaran langsung, maupun online merupakan suatu bentuk komunikasi. Sebagaimana diungkapkan oleh Eriyanto bahwa komunikasi media apabila dipandang dari sudut konstruksionis, maka media tidak hanya sekedar sebagai saluran, melainkan sebagai subjek yang dapat mengkonstruksikan realitas, lengkap dengan pandangan-pandangan yang sudah pasti memihak (Syarifah, 2012:7)

Teori propaganda Lasswell memadukan ide-ide yang dipinjam dari behaviourisme dan Freudianisme menjadi visi media yang pesimistis dan peran mereka dalam menempa tatanan sosial modern. Lasswell adalah salah satu ilmuwan politik pertama yang dikenal kegunaan berbagai teori psikologi dan untuk menunjukkan bagaimana mereka dapat diterapkan untuk memahami dan mengendalikan politik. Kekuatan propaganda bukanlah hasil dari substansi atau daya tarik pesan-pesan tertentu tetapi, lebih tepatnya, hasil dari kondisi pikiran yang rentan dari orang kebanyakan. Lasswell berpendapat bahwa depresi ekonomi dan meningkatnya konflik politik telah menyebabkan psikosis meluas, dan ini membuat kebanyakan orang rentan terhadap bentuk kasar dari propaganda. Ketika orang biasa dihadapkan setiap hari oleh ancaman kuat untuk kehidupan pribadi mereka, mereka beralih ke propaganda untuk jaminan dan cara untuk mengatasi ancaman. Ketika orang-orang menganggur dan rumah mereka disita, banding propaganda menemukan audiens yang siap (Stanley \& Davis, 2013:48)

Istilah firehose of falsehood sebagaimana diungkapkan dalam kolom media Tempo.co, bahwa strategi "firehose of falsehood" menempatkan seseorang menjadi kontroversial, rasis, dan selalu memiliki pandangan buruk terhadap apa yang di lihatnya. Tapi pada saat yang sama, disana juga seseorang dapat memperoleh keuntungan elektoral dari rakyat baik secara diam-diam ataupun terbuka dalam pusaran kontroversi itu, sehingga publik akhirnya akan berharap perubahan dapat dilakukan oleh figur tersebut.

Strategi propaganda seringkali dimainkan oleh seseorang atau kelompok yang berkepentingan selama momentum masa kampanye berlangsung. Adapun modus dari propaganda adalah untuk mengkambing hitamkan lawan, tujuan utamanya tidak lain 
yaitu agar publik senantiasa lebih memberikan kepercayaan pada kelompoknya. Sehingga menjadi tidak asing lagi apabila momentum kampanye telah datang si kandidat dan timnya akan sibuk membangun narasi kegaduhan dari pada membangun visi dan misi. Seperti yang terjadi pada pemilihan presiden dan wakil presiden tahun 2019 kemaren, pasangan calon nomor 01 (Jokowi- Ma'ruf Amin) VS pasangan calon nomor urut 02 (PrabowoSandi), keduanya seringkali saling mengkambing hitamkan satu sama lain, oleh karena itu, keduanya memilih untuk menggunakan teknik propaganda "firehose of falsehood".

Kampanye politik adalah periode atau masa yang diberikan oleh panitia pemilu kepada semua kontestan, baik perseorangan maupun usungan partai politik untuk bisa memaparkan program kerjanya masing-masing dan mempengaruhi opini publik sekaligus memobilisasi masyarakat agar memberikan suara kepadanya pada saat pencoblosan. pada masa kampanye pemilihan presiden dan wakil presiden di Indonesia tahun 2019 kemarin (Damayanti \& Hamzah, 2017:8)

Apa yang sudah terjadi pada pemilihan presiden dan wakil presiden di tahun 2019 kemaren, merupakan sebuah relalitas bahwa kedua kubu menggunakan teknik ala Rusia dan Amerika itu. Sulit untuk di pungkiri karena fakta telah menunjukkan tentang bagaimana keduanya memainkan peran di Pilpres 2019 kemaren. Seperti hoax oleh tersangka Ratna Sarumpaet, boyolali, kampret, cebong, PKI, antek China, Islam Garis keras, dan lain sebagainya.

Fakta menunjukkan bahwa sejak tahun 2016 istilah propaganda ala Rusia atau yang dikenal dengan "firehose of falsehood" mulai banyak dikenal setelah sebuah lembaga think thank asal Amerika Serikat menerbitkan sebuah studi mengenai hal tersebut, disana dijelaskan bahwa strategi firehose of falsehood memanfaatkan kondisi psikologis seseorang yang terpapar informasi secara terus menerus, dapat kita lihat ciri dari pada strategi ini adalah memanfaatkan banyak sekali saluran informasi untuk membangun sebuah kepercayaan di tengah masyarakatdan itu dilakukan secara intensi dan ini pernah dilakukan oleh Donald Trump pada pemilihan presiden di Amerika tahun 2016 lalu, dan di pakai pula oleh kedua kubu pasangan Capres/Cawapres di Indonesia yang mengahdirkan calon nomor urut 01 Jokowi- Ma'ruf Amin Vs calon nomor urut 02 Prabowo- Sandiaga Uno.

Menurut Aditya dalam BBCnews.com, model-model kampanye seperti yang terjadi pada pemilihan presiden dan wakil presiden 2019 di negara kita, sudah pernah dilakukan Presiden AS Donald Trump dengan cara menyerang lawannya dengan isu-isu dan menggiring para pemilih pada tema seputar nasionalisme. "Itu kan cara atau strategi. Contohnya antek asing. Kalau kampanye Trump saat pemilihan kan mempertanyakan apakah Anda punya nasionalisme atau tidak? Diukur dari situ, 'ikut saya atau yang lain. Jadi nampaknya yang sedang dibangun isu populisme, bukan programatik. Memang mudah sekali isu seperti itu terangkat karena dekat dengan pemilih kan, apalagi soal identitas.

Argumen dari propaganda itu sendiri adalah memanipulasi sehingga dapat memunculkan emosi yang tidak masuk akal sekalipun tetap diyakini oleh kebanyak orang. seperti keyakinan pada rasis, tentang karakter orang Amerika yang tidak memiliki kulit putih atau bukan warga negara. Misalkan upaya propaganda anti-Semit dari rezim Nazi, yang dengan sengaja membangu kembali prasangka yang sudah ada sebelumnya (Corbin, 2020:11)

Propaganda "firehose of falsehood" merupakan bagian dari perkembangan dari sistem yang dianut oleh masyarakat secara umum dalam kehidupan berbangsa dan bernegara dengan menganut sistem demokrasi sebagai upaya untuk mencapai kesejahteraan bersama sebagaimana cita-cita undangundang. Dalam sebuah catatan sejarah, pengamat mengatakan bahwa , Kremlin, banyak memperoleh manfaat dari adanya kebebasan informasi di barat. Mudahnya penggunaan akses ke publik "untuk 
mendapatkan kredibilitas dengan menabur kebingungan kepada khalayak melalui teori konspirasi dan berkembang biak kepalsuan". Seperti munculnya outlet media terkemuka Kremlin, digunakan untuk mempromosikan narasi mendukung kepentingan Rusia dan membantu penyebaran disinformasi, atau contoh lain misalnnya gerai pro-Kremlin, yang melaporkan tentang kebohongan sebuah kasus adanya ledakan pabrik kimia di Lousiana, dan lain sebagainya (Arabidze, 2018).

Seiring pesatnya perkembangan arus globalisasi, mendorong semakin berkembangnya media massa, untuk membantu mempercepat seseorang dalam berkomunikasi maupun bekerja, termasuk menggunakan media massa dalam momentum kampanye politik sehingga istilah firehose of falsehood, hari telah menjadi sangat populer sekali di masyarakat. Menurut Paul dan Matthews (2016), firehose of falsehood memiliki ciri yaitu, lacks commitment to consistency, lacks commitment to objective reality, rapid, continuous and repetitive, high voluve and multichannel propaganda.

Diterapkannya strategi propaganda atau kepalsuan (firehose of falsehood) di media massa, baik televisi, media cetak, dan media online. Secara masif dan sistematis turut menodai perjalanan proses pemilu 2019. Bahkan pada plikada tahun 2018 saja setidaknya sudah tercatat kurang lebih ada 3884 kasus hoax dan hate speech yang kemudian di selidiki oleh penyidik Polri. Dan di tahun 2019 semakin gaduh saat pertarungan di Pilpres menghadirkan Petahana melawan penantang setia Prabowo Subianto. Strategi firehose of falsehood yang dianut dari Rusia dan Amerika itu, justru menjadikan perjalanan pemilu kurang efektif dan menurunkan kepercayaan publik kepada pemerintah secara general (Golose, 2019:8).

Propaganda "firehose of falsehood" dapat berkembang pesat karena adanya dorongan kuat dari berkembangnya media massa yang mampu mengkonstruk banyak lapisan masyarakat. Sehingga kampanye dapat berjalan terkoordinasi dengan baik untuk mendorong berita palsu dan jenis disinformasi lainnya. Sebagian besar berita di Twitter mengikuti pola yang teratur secara statistik: Tingkat tautan baru meningkat dengan cepat (tetapi tidak secara instan), memuncak dalam satu atau dua jam, dan kemudian meluruh secara eksponensial, secara statistik teratur, tapi banyak berita palsu tidak mengikuti pola yang universal ini. Blok akun yang terorganisir tampaknya berkoordinasi untuk memperpanjang siklus hidup berita dan tagar yang dipilih. Segmen peta terkait propaganda Rusia adalah peserta kunci dalam kampanye ini, banyak dari upaya ini selaras dengan tujuan dan minat Rusia (Mathew dan Barash, 2018: 6).

Berita adalah sebuah konstruk realitas yang mampu seolah nyata jika diperkukuhkan dengan dukungan media. Dimana media massa memiliki kesanggupan dalam menularkan dan menyuapkan pokok ide, bahkan jika perlu menjungkir balikkan keadaan yang tengah berlangsung. Surat kabar adalah salah satu komunikasi massa yang merepresentasikan realitas sosial. Suatu realitas yang berkembang dimasyarakat merupakan suatu hasil konstruksi realitas yang dimuat dimedia massa (Nurcahyo, 2015:3)

Berdasarkan paparan diatas dapat penulis katakan bahwa berkembangnya istilah Propaganda Firehose of Falsehood di Indonesia itu karena pengaruh media massa yang semakin hari semaki pesat dan masyarakat juga semakin mellek media, sehingga propaganda yang dilakukan oleh kedua pasangan calon presiden dan wakil presiden pada pemilihan 2019. Tanpa media massa teknik propaganda yang dijalankan oleh kedua pasangan calon presiden dan wakil presiden di tahun 2019 kemarin tidak akan bisa berjalan. Propaganda firehose of falsehood memiliki hubungan sangat erat dengan media atau dalam kata lain tidak dapat dipisahkan satu dengan yang lainnya.

Berdasarkan hasil wawancara peneliti dengan kedua tim pasangan calon presiden dan wakil presiden pada pemilu tahun 2019 kemarin, dapat disebut bahwa kedua pasangan 
calon presiden dan wakil presiden menggunakan teknik propaganda firehose of falsehood walaupun secara terus terang ketika kedua belah pihak, tim pasangan calon presiden dan wakil presiden tidak mengakui bahwa kelompoknya telah melakukan teknik ala Rusia itu. Namun dengan praktik-praktik yang terjadi dilapangan disebutkan oleh pengamat bahwa keduanya telah menggunakan teknik propaganda firehose of falsehood.

Misal kalau kita perhatikan munculnya kegaduhan di masyarakat akibat kampanye kedua pasangan calon presiden dan wakil presiden yang masing-masing saling serang lewat media sosial sehingga masyarakat terprovokasi, seperti munculnya istilah cebong, kampret, antek PKI, surat suara tercoblos, islam garis keras, kasus hoaxs yang di dalangi oleh tersangka Ratna Sarumpaet, LGBT, larangan Adzan, dan sebagainya. Caracara seperti ini merupakan bagian dari teknik propaganda firehose of falsehood yang mana tujuannya agar masyarakat terprovokasi dan ikut golongannya, artinya siapa yang mampu meyakinkan khalayak lewat media sosial maka secara otomatis kelompok itulah yang akan mendapatkan banyak simpati dari khalayak.

Cara-cara seperti disebut atas adalah bentuk propaganda atau kampanye hitam dimana pihak lawan memberikan name calling dengan seburuk mungkin dengan tujuan masyarakat juga ikut benci seperti yang terjadi pada pemilihan presiden dan wakil presiden di tahun 2019 kemarin yang memunculkan banyak sebutan. Mulai dari boyolali, PKI, Anti-Islam, cebong, Kampret dan sebagainya.

Karakter dari pada teknik propaganda firehose of falsehood ini, bergantung pada media sosial. Cara mempengaruhi masyarakat umum lewat media sosial dan itu dilakukan secara terus menerus hingga akhirnya masyarakat luas seperti terhipnotis.

\section{SIMPULAN}

Berdasarkan keterangan yang ada, dapat peneliti simpulkan bahwa kedua pasangan calon Presiden dan Wakil Presiden yang berlangsung pada tahun 2019 kemarin, masing-masing kedua pasangan calon Presiden dan Wakil Presiden baik nomor urut 01 maupun nomor urut 02, telah menggunakan kampanye ala Rusia dan Amerika yang di kenal dengan istilah Propaganda "firehose of falsehood" hal itu jelas terlihat dimana kedua pasangan calon non-send dalam penyampaian visi dan misi, tapi lebih banyak membangun ujaran kebencian di tengah masyarakat. Seperti munculnya istilah cebong, kampret, antek PKI, Islam Garis keras, dan sebagainya. Dan itu sengaja di bangun oleh kedua pasangan Capres/Cawapres di tahun 2019. Firehose of falsehood dilakukan melalui media massa seperti televisi, media cetak, dan online untuk mempengaruhi khalayak umum. Dan itu di lakukan secara masif oleh masing-masing, kedua pasangan calon Presiden dan Wakil Presiden. Guna untuk mempengaruhi masyarakat umum agar bisa mencapai tujuan yang di inginkannya, yakni memperoleh kemenangan.

\section{DAFTAR PUSTAKA}

Arabidze, I. (2018). Russian Disinformation and Propaganda: Old Strategy in a New Cover? The Pardee Periodical Journal of Global Affairs, 3(1).

Arifin, A. (2010). Pers dinamika Politik: Analaisi Media Komunikasi Politik Indonesia: pertarungan politik dan ideologi pers perjuangan, pers aliran, pers partai, pers partisan,pers pemerintah, dan pers independen di Makassar, 1945-1966. Yarsif Watampone.

Corbin, C. M. (2020). The Unconstitutionalty Of Goverment Propaganda. Ohio State Law Journal, Januari.

Damayanti, Novita, Hamzah, R. E. (2017). Strategi Kampanye Politik Pasangan Jokowi-JK Pada Pemilihan Presiden dan Wakil Presiden 2014. Jurnal Wacana, $16(2)$

Gabriel A. Almond dan James S. Coleman. (1960). The Politicis of the Developing Areas. Princeton University Press.

Golose, P. R. (2019). Strategi penanganan 
firehose of falsehood pada Era post-truth. Jurnal Ilmu Kepolisian, 13(1).

Hafied Cangara. (2009). Komunikasi Politik: Konsep, Teori, dan Strategi. Rajawali Pers.

Harold D Laswell. (2006). World Revolutionary Propaganda. Borzoi book.

Heryanto, G. G. (2018). Media Komunikasi Politik. IRCiSoD.

Nurcahyo, D. (2015). Analisis Wacana Pemberitaan Pencalonan Jokowi sebagai Calon Presiden 2014 Pada Surat KabarHarian Kompas. Jurnal Wacana, 14(4).

Nyarwi, A. (2012). Manajemen Komunikasi Politik \& Marketing Politik. Pustaka Zaman.

Ramlan Surbakti. (2007). Memahami Ilmu Politik. PT Grasindo.

Salim, A. (2006). Teori dan Paradigma:
Penelitian Sosial. Tiara Wacana.

Srisadono, W. (2018). Komunikasi Publik Calon Gubernur Provinsi Jawa Barat 2018 Dalam Membangun Personal Branding Menggunakan Twitter. Jurnal Pustaka Komunikasi, 1(2).

Stanley, J. (2015). How Propaganda Work. Princeton University Press.

Stanley, J. B. and dennis K. D. (2013). Mass communication theory. Nelson Education, Ltd.

Sugiono. (2011). Metode penelitian pendidikan. Alfabeta.

Sujarwandi, V. W. (2014). Metodologi Penelitian. Pustaka.

Syarifah, S. A. (2012). Analisis Wacana Pencitraan Presiden Susilo Bambang Yudhoyono Dalam Buku Pak Beye dan Istananya. Jurnal Wacana, 11(2), 188201. 